\title{
The European Sovereign Debt Crisis as an Issue of Accountability, Representation, and Control
}

\author{
Hamad Alhumoudi \\ Independent Research, UK \\ E-mail: hamad.1992@hotmail.com
}

Received: August 18, 2018 Accepted: September 16, 2018 Published: December 31, 2018

doi:10.5296/ijafr.v8i4.13742

URL: https://doi.org/10.5296/ijafr.v8i4.13742

\begin{abstract}
This paper aims to provide an overview of the European sovereign debt crisis and its causes and effects. In particular, it will focus on Greece sovereign debt crisis and discuss the immediate trigger point of the Goldman Sachs Bank fraud, using the concept of Accountability, Representation and Control (ARC) and its implications for international interdependence. This paper relies on qualitative document analysis of previous research to analysis the European sovereign debt crises and its causes. Based on the available evidence, some accountability issues have been found, illustrating how the Greek government mismanaged public finances by borrowing and spending high, as well as by failing to control important issues such as tax evasion. On the other hand, the European Monetary Union (EMU) also has accountability issues, due to its regulations; it has been described as negligent by some authors, as it facilitated Goldman and the Greek government's non-disclosure of their deal in financial statements.
\end{abstract}

Keywords: Accountability, Representation, Control, EMU, ARC, European, Monetary, Union

\section{Introduction}

Numerous authors, scholars and researchers from around the world have explored the Euro zone sovereign debt crisis, which in part resulted from the debt crisis affecting countries such as Portugal, Ireland, Italy, Greece and Spain (so-called "PIIGS"). This paper aims to provide an overview of the European sovereign debt crisis and its causes and effects. In particular, it will focus on Greece sovereign debt crisis and discuss the immediate trigger point of the Goldman Sachs Bank fraud, using the concept of Accountability, Representation and Control (ARC) and its implications for international interdependence. Based on the available evidence, some accountability issues have been found, illustrating how the Greek government mismanaged public finances by borrowing and spending high, as well as by failing to control important 


\section{Ml Macrothink}

International Journal of Accounting and Financial Reporting

ISSN 2162-3082

2018, Vol. 8, No. 4

issues such as tax evasion. On the other hand, the European Monetary Union (EMU) also has accountability issues, due to its regulations; it has been described as negligent by some authors, as it facilitated Goldman and the Greek government's non-disclosure of their deal in financial statements. It can be concluded that the relationship between ARC and the Greek debt crisis are interlinked. The paper is divided into three sections. The first section is an overview of the crises. The second section is the discussion of the crises based on prior and existing literature. The third section is the conclusion.

\section{Overview of the Crisis}

According to Karanikolos et al. (2013), it was the 2008 US financial crunch that originated from subprime mortgage loan market instability that caused the Eurozone a sovereign debt crisis. The US financial meltdown caused public debt to plummet dramatically in numerous developed countries (Kouretas, 2010: Samitas \& Taskalos, 2013). Evidence shows that a petty instability was responsible for the Greek government's Bond payment crisis, which caused extensive damage across the Eurozone as well as to the BRICS economies, due to the interdependence between financial institutions (Rengasamy 2012; Ali 2012).

According to experts, the crisis was prompted by a combination of serious issues that were already evident in the Eurozone economies and country-specific factors (Nelson et al, 2012). The inflow of capital and later developments in public and private lending over the preceding 10 years to 'peripheral' European economies (like Spain, Ireland, Portugal, Greece, etc.) exaggerated the disaster (Belkin \& Mix, 2010). With the advent of a common currency, the Euro, these economies transitioned from state-governed currencies; however, this caused their bond circulations rapidly reduced. This affected the interest rates offered by the already strong or core countries (e.g. Germany) in the European Union (Rahbari, 2012). A consequence of this was that, as the periphery countries' public and private sectors transitioned to the Euro they found it cheaper to borrow from the global market, resulting in massive current account deficits, and poorly managed capital inflows (Alogoskoufis, 2012).

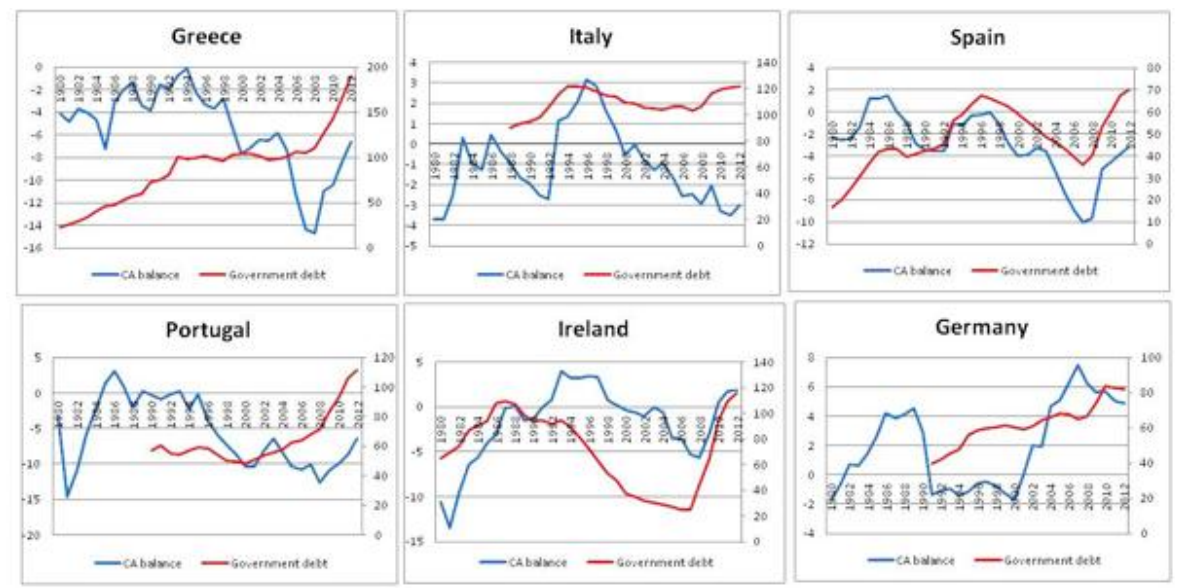

Source: Atoyan et al (2013).

Figure 1. Looks at each country's Current Account CA deficit (lest axis) compared with gross government debt (right axis), both in percentage of nominal GDP 


\section{MInstitute ${ }^{\text {Math }}$}

International Journal of Accounting and Financial Reporting ISSN 2162-3082

2018, Vol. 8, No. 4

The above graph illustrates that, before the crisis began, in fact, ever since the Euro was introduced, current account (CA) deficit were emerging in peripheral countries. Meanwhile, Germany witnessed an increasing CA surplus. Although Greece had had no CA surplus for more than 30 years, other countries like Italy, Ireland, Spain and Portugal did have one before entering the Euro. However, from 2000 onwards surpluses declined (Belkin \& Mix, 2010; Reinhart \& Roggof, 2009; Higgins \& Klitgaard, 2011).

In response debts soared; in economies like that of Greece, debt was concentrated in the public sector, since public budgets were being seriously mishandled. In other economies such as Spain and Ireland, the debt accumulation was in the private sector leading to risky banking practices and a real estate crunch (Lane, 2012). Prior to the crunch, the fiscal position was satisfactory, as the budget was balanced while debt increased. However, in the wake of bankruptcies and bailout packages, the Spanish construction sector consumed massive capital, causing revenue shortages and mounting expenditure leading to an uncontrollable budget deficit (Roman \& Bilan 2012). Similarly, large public projects, such as the stadium for Euro 2004, caused Portugal to overspend its budget. Thus, similar issues in public services, investment, etc. led to the economic crunch and an unstable fiscal position (Nelson et al, 2012). With the freezing of the capital sector, governments, households and organisations found it difficult to acquire further borrowing while managing current levels (Ail, 2012). In addition, the financial crunch and the resulting stagnation halted public investment, since tax revenues were falling and government spending was rising (Samitas \& Tsakalos, 2013). In a few instances, private sector loans were assumed by the government (most notably in Ireland), which also guaranteed bank debt. Default on borrowings was the option preferred by some economies (Shambaugh, 2012; Mayer, 2012). Thus, increasingly, peripheral countries found it hard to acquire loans on the global markets, becoming reliant on cheap international investment to support their consumption and spending. Restriction of credit became a challenge for these countries. Serious domestic crises were exacerbated by problems outside the Eurozone, superficially, the eventual historic debt crisis (Kouretas, 2010).

\section{Discussion of the Greek Case Using ARC}

Foley et al. (2011) reported that it was primarily accounting fraud at Goldman Sachs that triggered Greece's debt crisis. Prior to the crisis accountability problems manifested in the Goldman Sachs case. In 2000 and 2001, Greece entered into a cross-currency swap agreement with Goldman Sachs, to join the European Union. This allowed Greece to acquire additional future loans for lower debts and at a lower deficit rate (Yang \& Lei, 2012). In 2009, after assuming power, the new Greek government found that the previous regime had maintained financial stability; thus, it increased the fiscal deficit to $12.7 \%$, surpassing the $3 \%$ limit. In reality, in contrast to what had been reported to the European Union (EU), the Greek deficit crisis in reality had spanned at least 10 years (Jiao, 2013). Once this was discovered, Greece's sovereign rating plummeted and rating agencies moved in to evaluate the new situation. In July 2011, Greece received its worst "CC" rating, making it the lowest economy in the entire Eurozone, suggesting to foreign investors that Greece was the equivalent of a financial black hole (Cnn.com, 2012; Barth et al, 2011). Initially, the government proposed the debt be exchanged for the dollar and yen instead of the euro, so that it could later return to its original 
currency (Gillbert, 2010). European leaders were critical of Goldman Sachs for misleading Greece and concealing the extent of the debts spanning many years (Moya, 2010; Quinn 2010; Thompson, 2013).

The previous Greek government raised the issue of accountability in the Goldman case, and it may be held accountable for decreasing the amount of debt (Boven, 2009). Roberts and Scapens (1985) noted that holding someone accountable for an action, means asking them to justify it. In fact, the Greek government, in regard to the accountability issue, has been shown to have mishandled public investments by rampant tax dodging and unnecessary borrowing as well as excessive expenditure on public development and employment. Although the government, after cutting a deal with Goldman, was able to reduce its debts somewhat, it eventually had to sign a Stability and Growth Pact (SGP) treaty to enter in the Euro (Vlamis, 2013). Consequently, in 2009, the debt crisis became more evident, as the new government shared its astounding budget deficit; i.e. $12.7 \%$ of Gross Domestic Product (GDP) in contrast to the initially admitted $3.7 \%$. It was implied that the preceding government was responsible due to their deal with Goldman (Jiao, 2013; Vlamis, 2013).

Lack of accountability has a severe impact, as it permits corruption and minimises economic development (Pegasus, 2011). In 2009, in Greece, tax evasion by self-employed citizens alone was reported to be €28bn; overall the reported tax base was $€ 98 \mathrm{bn}$, in contrast to $€ 235 \mathrm{bn}$ GDP. This indicates that a huge sum remained unpaid. This represented half of Greece's budget, at a tax rate of 40\%; a rise from 31\% in 2009 (Inman, 2012). Both the EU and the International Monetary Funds (IMF) criticised Greece's failure to monitor over $€ 30 \mathrm{bn}$ of the country's revenues. The two players offered help to Greece, but argued that the government's lack of taxation controls were a barrier to assistance. The EU and IMF held the Greek government responsible for austerity cuts and more productive monitoring of its tax base (Economist.com, 2012). According to Inman (2012), some politicians and banks were also evading tax; these problems need to be address to insure accountability.

Accountability requires effective monitoring from an impartial source; since the Greek debt crisis the EMU have become responsible for governing monetary policy, and also oversee, to a limited extent, economic and fiscal policies within the euro-zone. All nations that use the euro can be held accountable to the European parliament (Boven, 2009; Ec.europa.eu, 2013); however, it is not always able to perform its duties (Story et al, 2010). For their part, Goldman's representatives argued that debt reduction could be ignored in the wake of swaps in regard to the Euro rules (Foley, 2011). It was also argued that swapping could be employed among different European government while meeting the terms of the Maastricht Treaty (Richard, 2012).

Representation was another important factor implicated in Greek and Euro debt disaster. Representation, taken literally, denotes 'thing' identified as 'standing for' another (Young, 2006). Zuboff (1988) analysed three kinds of representations; remote, dislocation and contraction. It may be argued that representation functions as a distant control that shows authority when delegating power to responsible agents. Thus, it may result in the substitution of actual happenings and not real events in their own right (Lilley et al, 2004). The entire 
account of the Greek debt crisis, including the government's clever deal with Goldman Sachs (and its deception), can be regarded as a representation of the crisis. Thus, it is clear that the entire situation could be justified on three grounds, as introduced by Zuboff. It is also possible that distant monitoring, contraction and dislocation are also happening here. Distant monitoring, in the form of the currency-swap decision by the Greek government with Goldman Sachs (actually in the US) involved the managing of affairs distantly. Dislocation is evident in the Goldman deal, since the deal was cut on the data available that suggested Greece was doing well (Foley et al, 2011). This misinformation was also used to help it to join the Euro. Contraction was achieved in the wake of the hiding of the debt by Goldman; this superficially showed a lesser and manageable degree of debt; however, in real terms, the situation was much worse. The Goldman deal misled the regulators and investors, as debts were not registered as loans. This also hid the country's liabilities during the currency swap (Story et al, 2010; Gilbert, 2010; Young and Semmler, 2012).

In 2004, an external audit, in the aftermath of this situation, revealed that loopholes had caused the Greek crisis, leading to the alteration of the EU authoritative regime (Harford, 2013). In, 2009, as a severe economic crisis developed in Greece, EU authorities became increasingly suspicious owing to the lack of credibility of accounting mechanisms and audits (Bernhard et al, 2011). This also badly affected the financial and political scene within the country (Harford, 2013). For example, it became public that Greece had made an off-market deal with Goldman in 2001 for a currency swap, over the period 2006 to 2009 (Gilbert, 2010). In also included the regularization of debt and deficit levels. Thus, the EU brought in institutional level reforms for handling fiscal data in Greece (Europarl.europa.eu, 2013).

To understand the issue, it is significant to comprehend the notion of control. In the wake of the Goldman scandal, the Greek authorities managed their affairs, such as expenditure poorly, while in the Euro (Vlamis, 2013). Since expenditure had been high over the preceding decade, this resulted in serious levels of deficit. Oced (2012) opines that it is improvements in administrative matters that can help better control government expenditures. Cutting down public wage levels and developing effective mechanisms for the public and health sectors can help to establish effective public organisations that can in turn result in better monetary controls. For instance, the health system in Greece employs traditional approaches to cost management. In theory Armstrong argued that better management control can be achieved by introducing accounting based systems that discipline all activities against target budgets (Armstrong, 2002). Similarly, Bellas et al (2009) argue that one such solution would be to employ the Activity Based Costing (ABC) Method to assist the government to control financial matters more effectively. Otley and Bery (1980), in contrast, suggest that no single accounting approach can capture every single aspect of finance. This implies that it is not in any single approach that the solution lays, but in the overall conduct of fiscal policy.

According to Otley and Bery (1980), control mechanisms can be developed in line with authorities' capability to intervene in accounts, and by regulating required parameters that can use human resources effectively. Ali (2012) contends that it was the weaknesses of overall monetary mechanisms and the lack of effective human resource management that emerged in the wake of the Greek crisis. This was mainly due to the deceptions with which 
the country had entered the Euro, as detailed above. Similarly, Lane (2012) and Davis (2011) argue that both the EU and European Central Bank (ECB) failed to put in place effective policies for financial and budgetary matters, mainly because the EU had no central policy regime to manage economic matters. This is what first prompted Goldman Sachs to come forward to assist Greece in the scam. But this is also evidence of the poorly maintained monitoring mechanisms of the Eurozone. Thus, it could be argued that the Eurozone requires a stable financial supervisory agency or agencies to ensure that financial activities are honest and openly disclosed (Solom et al, 2012).

The advent of this disaster also uncovered problems in other areas such as regulation; public debt should not be allowed to exceed a $60 \%$ limit and annual public deficit should be set at $3 \%$ of GDP if governments are to sustain their monetary policies. Some experts even argue that the entire Eurozone suffers from lax budgetary and economic policies. Certainly, at present, many Eurozone economies are still in crisis (e.g. Spain and Greece); it is evident that Stability and Growth Pact rules are no longer respected (Ali, 2012). These facts are due directly to institutional deficiencies in the Eurozone. It is important to remember that the major players within the EU (Germany and France) were the first to annul the budget-related regulations put in place when the Euro was initially announced. This is why other members sought out other means to avoid compliance. However, this did create a Utopian feeling in Greece and its public enjoyed the fruits of fraud for a long time (Erain, 2012).

In contrast, (Roman and Bilan, 2012; Chibber, 2011) assert that the so-called Troika, EU, ECB, and IMF, reacted rapidly to help sustain economic stability. Their support was instrumental in the dire collapse of the relevant institutions and the whole system. Greece was eventually granted $£ 110$ bn for a bailout, and they did try to prevent the crisis (Davis, 2011). In addition, the EU authorities and the ECB acted to gain back investors' trust by buying bonds from the countries in crisis to contribute greater liquidity to their markets.

Darvas (2012) notes that today the relationship between the countries is much stronger than it was before the crisis, since it is now recognised that contagion can be caused by private sector defaults in smaller countries like Greece. For instance, Cyprus, which was previously doing well, received a severe blow from the crisis due to loans to Greece, amounting to around $160 \%$ of the country's GDP. It was not possible for the government to bail out all the banks owing to slow economic development and difficulty in winning support from global investors and lenders (BBC.co.uk, 2013). In contrast, any large country will go into full meltdown if it suffers default. For instance, Italy was prevented from becoming bankrupt, since this would have sunk its entire banking sector, and shaken up the entire Eurozone banking sector fuelling unpredictable global economic crisis. As argued by the ECB (2012), if financial integration is to be maintained to a proper level, this channel will remain important. On the other hand, the figure below illustrates how the PIIGS countries' suffered exposure to debt crisis individually. In the case of Greece, its local banks, along with the German and French banks (and insurance companies) held the largest share of Greece's sovereign debt and this clearly show the effect of the crisis on the international interdependence (Ft.com, 2013; Armitstead, 2012). 


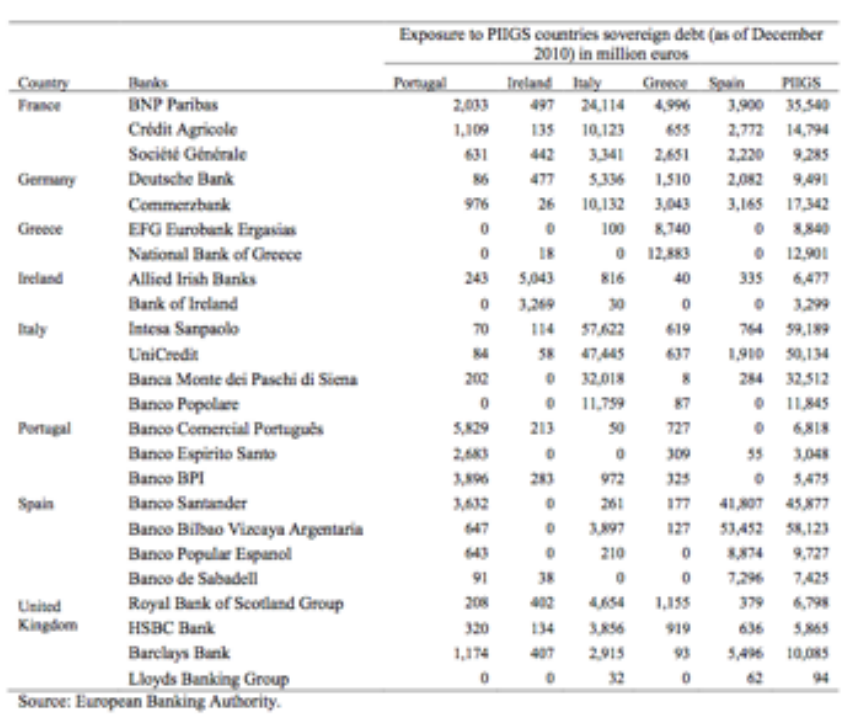

Figure 2. Exposure to PIIGS countries sovereign debt

\section{Conclusion}

In conclusion, this paper has briefly analyzed the causes and effects of the Euro debt crisis. Furthermore, the essay has focused on the role of Greece and Goldman Sachs in the crisis, in particular the committing of fraud. However, the essay used the ideas of ARC to explain the reason for the Greek sovereign debt crisis, which had an implication on the Euro zone countries, and international interdependence. However, the evidence supports conclusions as to the reasons for the occurrence of the Euro sovereign debt crisis from the perspective of Greece; i.e. that the accountability mechanism is not adequately responsible. First, it has been argued that the lack of representation and the fraudulent accounting in Greece gave birth to the crisis. Second, lack of robust monitoring, supervision and management mechanisms in the Eurozone can be regarded as another factor. Finally, it has been shown that it was poor systems and ineffective financial mechanisms that caused the crisis to continue as long as it did.

From the perspective of other countries in the Eurozone, reliance on huge levels of cheap foreign borrowing supported the wealthy countries to grow. Thus, the credit-fueled construction booms and estate bubbles led investors to go bankrupt when faced with crisis. It has been suggested that more controls should be introduced in the Eurozone, and that the PIIGS countries should restructure their debt and follow the austerity measures set put by the Troika, in order for governments more effectively promote economic growth.

\section{References}

Aleksandra, R. (2007). University of Glasgow. Retrieved November 29, 2013, from http://eleanor.lib.gla.ac.uk/record=b2500627

Ali, T. (2012). The Impact of the Sovereign Debt Crisis on the Eurozone Countries. Retrieved November 29 , 2013, from http://www.sciencedirect.com/science/article/pii/S1877042812035100 
Alogoskoufis, G. (2012). Greece's Sovereign Debt Crisis: Retrospect and Prospect. Retrieved November 29, 2013, from http://eprints.lse.ac.uk/42848/1/GreeSE\%20No54.pdf

Anand, M., Gupta, G., \& Dash, R. (2012). The euro zone crisis its dimensions and implications. $\quad$ Retrieved November 17, 2013, from http://mof.gov.in/workingpaper/euro_zone_crisis.pdf

Armitstead, L. (2012). What's the Greek debt crisis all about?. Retrieved November 19, 2013, from

http://www.telegraph.co.uk/finance/financialcrisis/9098559/Whats-the-Greek-debt-crisis-allabout.html

Armstrong, P. (2002). Management, Image and Management Accounting. Critical Perspectives on Accounting, 13(3), 281-296

Atoyan, R., Manning, J., \& Rahman, J. (2013). Rebalancing: Evidence from Current Account Adjustment in Europe. Retrieved November 17, 2013, from http://www.imf.org/external/pubs/ft/wp/2013/wp1374.pdf

Barth, J., Angkinand Prabha, A., \& Yun, G. (2011). The Eurozone Financial Crisis: Role of Interdependencies between Bank and Sovereign Risk. Retrieved November 29, 2013, from http://papers.ssrn.com/sol3/papers.cfm?abstract_id=1966295

BBC News. (2013). Q\&A: Cyprus deal. Retrieved November 19, 2013, from http://www.bbc.co.uk/news/business-21922110

Belkin, P., \& Mix, D. (2010). Greece's Debt Crisis: Overview, Policy Responses, and Implications. $\quad$ Retrieved November 29, 2013, from http://www.fas.org/sgp/crs/row/R41167.pdf

Bellas, A., \& Thanasas, G. (2009). Health Services in Greece: An Approach to Their Operational Cost. Retrieved November 26, 2013, from http://papers.ssrn.com/sol3/papers.cfm?abstract_id=1684259

Bernhard, R., Gottsche, M., Gernot, B., \& Stefan, E. (2011). Fact and Fiction in EUGovermental Economic Data. German Economic Review, 12(3), 244-254.

Boven, M. (2009). Public Accountability a framework for the analysis and assessment of accountability arrangements in the public domain. Retrieved November 27, 2013, from http://www.qub.ac.uk/polproj/reneg/contested_meanings/Bovens_Public\%20Accountability.c onnex2.doc

Chibber, K. (2011). Who are the troika?. Retrieved December 18, 2013, from http://www.bbc.co.uk/news/business-15149626

Darvas, Z. (2012). Bruegel: The euro crisis: ten roots, but fewer solutions. Retrieved November 29, 2013, from http://www.bruegel.org/publications/publication-detail/publication/755-the-euro-crisis-ten-ro ots-but-fewer-solutions/ 
Davis, H. (2011). The European Sovereign Debt Crisis: The Beginning of the End or the Beginning of a New and Strengthened Union?. Retrieved November 29, 2013, from http://www.stlawu.edu/sites/default/files/resource/Davis\%20EU\%20SYE\%20Final\%20revise d.pdf

Davison, C. (2012). Foucault: Society and Prison. Retrieved November 29, 2013, from http://www.academia.edu/344213/Foucault_Society_and_Prison

Ec.europa.eu. (2013). Who does what in EMU. European Commission. Retrieved November 29, 2013, from http://ec.europa.eu/economy_finance/euro/emu/who/

Edition.cnn.com. (2012). Q\&A: Greece's financial crisis explained. Retrieved November 19, 2013, from http://edition.cnn.com/2010/BUSINESS/02/10/greek.debt.qanda/

Erian, M. (2012). Who is to blame for Greece's crisis?. Retrieved November 19, 2013, from http://www.theguardian.com/business/economics-blog/2012/may/18/who-blame-greece-crisis

Europarl.europa.eu. (2013). Debates - Quality of statistical data in the Union and enhanced auditing powers by the Commission. Retrieved November 28, 2013, from http://www.europarl.europa.eu/sides/getDoc.do?type=CRE\&reference=20100615\&secondRe $\mathrm{f}=\mathrm{ITEM}-006 \&$ language $=\mathrm{EN}$

European Banking Authority. (2011). EU - wide stress test aggregate report. Retrieved $\begin{array}{lll}\text { November 29, 2013, from } & \text { 29 }\end{array}$ http://online.wsj.com/public/resources/documents/EUSTRESS0715.pdf

Financial Times. (2013). Banks brace for hits on Greek bonds. Retrieved November 19, 2013, from

http://www.ft.com/cms/s/0/13e33e54-b3b8-11e0-855b-00144feabdc0.html?siteedition=uk\#ax zz217OyfifQ

Foley, S. (2011). What price the new democracy? Goldman Sachs conquers Europe. Retrieved November 15, 2013, from http://www.independent.co.uk/news/business/analysis-and-features/what-price-the-new-demo cracy-goldman-sachs-conquers-europe-6264091.html

Gilbert, M. (2010). Goldman Sachs Is Innocent of Greece's Swap Crimes: Mark Gilbert. Retrieved November 15, 2013, from http://www.bloomberg.com/news/2010-02-24/goldman-sachs-is-innocent-of-greece-s-swap-c rimes-mark-gilbert.html

Harford, T. (2013). Look out for No. 1. Retrieved December 18, 2013, from http://www.ft.com/cms/s/2/171aaa36-d8f1-11e0-aff1-00144feabdc0.html\#ixzz1XWna9dha

Higgins, M., \& Klitgaard, T. (2011). Saving Imbalances and the Euro Area Sovereign Debt $\begin{array}{lllll}\text { Crisis. } & \text { Retrieved } & \text { November } & \text { 29, from }\end{array}$ http://papers.ssrn.com/sol3/papers.cfm?abstract_id=1925018 


\section{MlMacrothink}

International Journal of Accounting and Financial Reporting

ISSN 2162-3082

2018, Vol. 8, No. 4

Hoskin, K., \& Macve, R. (1988). The Genesis of Accountability: The West Point Connections. Accounting Organizations and Society, 13(1), 37-73.

Inman, P. (2012). Primary Greek tax evaders are the professional classes. Retrieved November 28, 2013, from http://www.theguardian.com/world/2012/sep/09/greece-tax-evasion-professional-classes?CM $\mathrm{P}=\mathrm{twt} \_\mathrm{gu}$

Jiao, Y. (2013). The European sovereign debt crisis: a debt crisis and a sovereignty crisis. $\begin{array}{llll}\text { Retrieved November } & 29, & \text { from }\end{array}$ http://lup.lub.lu.se/luur/download?func=downloadFile\&recordOId=3878586\&fileOId=38785 87

Karanikolos, M., Mladovsky, P., Cylus, J., Thomson, S., Basu, S., Stuckler, D., ... Mckee, M. (2013). Financial crisis, austerity, and health in Europe. The Lancet, 381(9874), 1323-1331.

Kouretas, P. (2010). The Greek Crisis: Causes and Implications. Retrieved November 29, 2013, from http://www.panoeconomicus.rs/issue.php?id=41

Lane, P. (2012). The European Sovereign Debt Crisis. Retrieved November 19, 2013, from http://www.jstor.org/stable/41581131?origin=JSTOR-pdf

Lilley, S., Lightfoot, G., \& Amaral P. (2004). Representing Organization: Knowledge, Management and the Information Age. Oxford: Oxford University Press.

Mayer, T., Möbert, J., \& Weistroffer, C. (2012). Macroeconomic Imbalances in Emu and the Euro-system. $\quad$ Retrieved November 17, 2013, from http://www.cesifo-group.de/portal/pls/portal/docs/1/1215229.PDF

Moya, E. (2010). Goldman Sachs faces scrutiny over Greek debt swap. Retrieved November 15, 2013, from http://www.theguardian.com/business/2010/feb/18/greece-goldman-sachs-debt-derivatives

Nelson, R., Belkin, P., Mix, D., \& Weiss, M. (2012). The Eurozone Crisis: Overview and Issues for Congress. Retrieved November 29, 2013, from http://www.fas.org/sgp/crs/row/R42377.pdf

Nytimes.com. (2013). Wall St. Helped to Mask Debt Fueling Europe's Crisis. Retrieved November 15, 2013, from http://www.nytimes.com/2010/02/14/business/global/14debt.html?pagewanted=all\&_r=0

OCED. (2012). Greece at a Glance Policies for a Sustainable Recovery. Retrieved November 29, 2013, from http://www.oecd.org/greece/44785912.pdf

Otley, D. T., \& Berry, A. J. (1980). Control, Organization and Accounting. Accounting, Organizations and Society, 5(2), 231-244.

Pegasus, P. (2013). Fall evasion to $41.6 \%$ from $49 \%$ in last six months. Retrieved November 28, 2013, from http://www.ethnos.gr/article.asp?catid=22770\&subid=2\&pubid=29345 


\section{Mll Macrothink}

International Journal of Accounting and Financial Reporting

ISSN 2162-3082

2018, Vol. 8, No. 4

Quinn, J. (2010). Goldman Sachs faces Fed inquiry over Greek debt. Retrieved November 15, 2013,

from

http://www.telegraph.co.uk/finance/newsbysector/banksandfinance/7318877/Goldman-Sachs -faces-Fed-inquiry-over-Greek-debt.html

Rahbari, E. (2012). The European Central Bank as Lender of Last Resort for Sovereigns in the Eurozone -JCMS: Journal of Common Market Studies. Retrieved November 29, 2013, from http://onlinelibrary.wiley.com/doi/10.1111/j.1468-5965.2012.02275.x/citedby

Reinhart, C., \& Rogoff, K. (2009). The Aftermath of Financial Crises. Retrieved November 17, 2013, from http://www.nber.org/papers/w14656

Rengasamy, E. (2012). Sovereign Debt Crisis in the Euro Zone and its impact on the BRICS'S Stock Index Returns and Volatility. Retrieved November 29, 2013, from http://www.businessjournalz.org/articlepdf/EFR_2114april22.pdf

Richard, H. (2012). How Goldman Sachs helped mask Greece's debt. The Bureau of Investigative Journalism. Retrieved November 15, 2013, from http://www.thebureauinvestigates.com/2012/02/21/how-goldman-sachs-helped-mask-greeces -debt/

Roberts, J., \& Scapens, R. (1985). Accounting systems and systems of accountability Understanding accounting practices in their organizational contexts. Accounting Organizations and Society, 10(4), 443-456.

Roman, A., \& Bilan, I. (2012). The Euro Area Sovereign Debt Crisis and the Role of ECB's Monetary Policy. Retrieved November 29, 2013, from http://www.sciencedirect.com/science/article/pii/S2212567112002274

Shambaugh, J. (2012). The Euro's Three Crises. Retrieved November 29, 2013, from http://www.brookings.edu/ /media/projects/bpea/spring\%202012/2012a_shambaugh.pdf

Sikka, P. (2009). Financial Crisis and the Silence of the Auditors. Retrieved November 28, 2013, from http://www.essex.ac.uk/ebs/research/working_papers/wp_09-04.pdf

Solomos, D., \& Koumparoulis, D. (2012). The recent reform of European governance: A critical review. Inter Economics Journal, 47(5), 298-303.

Story, L., Thomas, L., \& Schwartz, N. (2010). The New York Times. Retrieved November 15, 2013, from

http://www.nytimes.com/2010/02/14/business/global/14debt.html?pagewanted=all\&_r=0

The Economist. (2012). A national sport no more. Retrieved November 28, 2013, from http://www.economist.com/news/europe/21565657-greek-tax-dodgers-are-being-outed-nation al-sport-no-more

Thompson, M. (2013). Greece joining euro was a mistake, says Merkel. Retrieved November 19, 2013, from http://money.cnn.com/2013/08/28/news/economy/merkel-greece-euro/ 


\section{Macrothink}

International Journal of Accounting and Financial Reporting ISSN 2162-3082 2018, Vol. 8, No. 4

Todorovic, M., \& Bogdanovic, J. (2011). The European Union Debt Crisis and the Eurozone's Survival. Retrieved November 29, 2013, from http://facta.junis.ni.ac.rs/eao/eao201102/eao201102-05.pdf

Tsakalos, I., \& Samitas, A. (2013). How can a small country affect the European economy? The Greek contagion phenomenon. Retrieved November 29, 2013, from http://www.sciencedirect.com/science/article/pii/S1042443113000061

Vlamis, P. (2013). Greek Fiscal Crisis and Repercussions for the Property Market. Retrieved November 17, 2013, from http://www.lse.ac.uk/europeanInstitute/research/hellenicObservatory/CMS\%20pdf/Publicatio ns/GreeSE/GreeSE-No76.pdf

Yang, W., \& Lei, L. (2012). A Comprehensive Approach to the European Sovereign Debt Crisis Its roots, process and enlightenment on china. World Science Publisher, 2(2167-6429), 545-549.

Young, B., \& Semmler, W. (2012). The European Sovereign Debt Crisis: Is Germany to Blame?. $\quad$ Retrieved November $\quad 17, \quad 2013$, from http://www.uaces.org/archive/papers/abstract.php?paper_id=85

Young, J. J. (2006). Making up Users. Accounting, Organizations and Society, 31(1), $579-600$.

Zuboff, S. (1988). In The Age of the Smart Machine: The Future of Work and Power. New York, Basic Books.

\section{Copyright Disclaimer}

Copyright for this article is retained by the author(s), with first publication rights granted to the journal.

This is an open-access article distributed under the terms and conditions of the Creative Commons Attribution license (http://creativecommons.org/licenses/by/4.0/) 